\title{
STRESSOR RESPONSE MODEL FOR TAPE GRASS (Vallisneria americana) ${ }^{1}$
}

Frank J. Mazzotti, Leonard G. Pearlstine, Robert H. Chamberlain, Melody J. Hunt,

Tomma Barnes, Kevin Chartier, and Donald DeAngelis ${ }^{2}$

1. This document is CIR 1524, one of a series of the Wildlife Ecology and Conservation Department, Florida Cooperative Extension Service, Institute of Food and Agricultural Sciences, University of Florida. Original publication date January 2008. Visit the EDIS Web Site at http://edis.ifas.ufl.edu.

2. Frank J. Mazzotti, Associate Professor, Fort Lauderdale Research and Education Center (FLREC), Institute of Food and Agricultural Sciences (IFAS), University of Florida (UF); Leonard G. Pearlstine, Assistant Scientist, FLREC/IFAS/UF; Robert H. Chamberlain, Lead Environmental Scientist, South Florida Water Management District (SFWMD); Melody J. Hunt, Senior Environmental Scientist, SFWMD; Tomma Barnes, Consultant, Post, Buckley, Schuh \& Jernigan, Inc. (PBS\&J, Inc.); Kevin Chartier, GIS Applications Developer, FLREC/IFAS/UF; Donald DeAngelis, Landscape Ecologist, U.S. Geological Survey/University of Miami.

The Institute of Food and Agricultural Sciences (IFAS) is an Equal Opportunity Institution authorized to provide research, educational information and other services only to individuals and institutions that function with non-discrimination with respect to race, creed, color, religion, age, disability, sex, sexual orientation, marital status, national origin, political opinions or affiliations. U.S. Department of Agriculture, Cooperative Extension Service, University of Florida, IFAS, Florida A. \& M. University Cooperative Extension Program, and Boards of County Commissioners Cooperating. Larry Arrington, Dean 


\section{STRESSOR RESPONSE MODEL FOR TAPE GRASS (Vallisneria americana) ${ }^{1}$}

Frank J. Mazzotti, Leonard G. Pearlstine, Robert H. Chamberlain, Melody J. Hunt, Tomma Barnes, Kevin Chartier, and Donald DeAngelis ${ }^{2}$

\section{Introduction}

A key component in adaptive management of the Comprehensive Everglades Restoration Plan (CERP) projects is evaluating alternative management plans. Regional hydrological and ecological models will be employed to evaluate restoration alternatives and the results will be applied to modify management actions.

\section{Southwest Florida Feasibility Study}

The Southwest Florida Feasibility Study (SWFFS) is a component of the Comprehensive Everglades Restoration Plan (CERP). The SWFFS is an independent but integrated implementation plan for CERP projects that was initiated in recognition that some water resource issues (needs, problems, and opportunities) in Southwest Florida were not being addressed directly by CERP. The SWFFS identifies, evaluates, and compares alternatives that address those additional water resource issues in Southwest Florida. An adaptive assessment strategy is being developed that will create a systemwide monitoring program to measure and interpret ecosystem responses. The SWFFS provides an essential framework to address the health and sustainability of aquatic systems. This includes a focus on water quantity and quality, flood protection, and ecological integrity.

\section{C-43 West Basin Storage Reservoir Project}

The Caloosahatchee River (C-43) West Basin Storage Reservoir project is an expedited CERP project and a component of a larger restoration effort for the Caloosahatchee River and estuary. The purpose of the project is to improve the timing, quantity, and quality of freshwater flows to the Caloosahatchee River estuary. The project includes an above-ground reservoir with a total storage capacity of approximately 197 million cubic meters (160,000 acre-feet) and will be located in the C-43 Basin in Hendry, Glades, or Lee Counties. The initial design of the reservoir assumed 8094 hectares (20,000 acres) with water levels fluctuating up to 2.4 meters (8 feet) above grade. The final size, depth, and configuration of this facility will be determined through more detailed planning and design. 


\section{Objective}

The purpose of this stressor response model for the C-43 West Basin Storage Reservoir project and the Southwest Florida Feasibility Study is to portray species responses - both spatially and temporally - to changes in environmental variables resulting from restoration activities. The intent of the model is not to simulate the life cycle of the species, but rather to estimate numbers of habitat units to serve as a relative basis for comparing management alternatives. The tape grass model is one of a suite of Caloosahatchee estuary models including spotted seatrout, seagrass (Halodule/Thalassia), blue crab, and eastern oyster, which are being considered together for restoration plan evaluation. The other models are being documented in other reports.

\section{Forecasting Models}

Forecasting models bring together data resulting from research and monitoring studies within ecosystems and place them into an adaptive management framework for evaluation of alternative plans. There are two principle ways to structure adaptive management: (1) passive, by which policy decisions are made based on a forecasting model and the model is revised as monitoring data become available, and (2) active, by which management activities are implemented through statistically valid experimental design to understand better how and why natural systems respond to management (Wilhere 2002).

In an integrated approach that includes both passive and active adaptive management, a forecasting model simulates system response and is validated by monitoring programs to measure actual system response (Barnes and Mazzotti 2005). Monitoring can then provide information as a passive adaptive management tool for recalibration of the forecasting model. Directed research, driven by model uncertainties, is an active adaptive management strategy for learning and reducing uncertainties in the model (Ogden et al. 2003, Barnes and Mazzotti 2005).

The forecasting models for the C-43 West Basin Storage Reservoir project and the Southwest Florida Feasibility Study consist of a set of stressor response models (specifically, habitat suitability index models) for individual species. Each model is applied to restoration alternatives with the assumption that as stress levels on the ecosystem change for each alternative, so will extent and quality of suitable habitat.

\section{Habitat Suitability Index Model}

Habitat suitability index (HSI) models relate specific environmental requirements of an organism to the actual and/or simulated ecological properties of a study area. Parameters for environmental requirements were defined based on existing literature, expert knowledge, and currently available field data. Values were adjusted for local conditions and then used to create individual suitability indices that drive the model. Suitability values for the individual parameters and for the calculated HSI are represented from zero (unfit habitat) to one (ideal habitat), and are presented in line graphs below (Figure 6, Figure 7, Figure 8, Figure 12). The HSI model uses a formula (see HSI Formula section below) to calculate habitat suitability monthly as the weighted geometric mean of the specific environmental variables. Because the geometric mean is derived 
from the product of the variables rather than the sum (as in the arithmetic mean), it has the property that if any of the individual variables are unsuitable for species success (i.e., the value of the variable is zero) then the entire index goes to zero.

The HSI model is incorporated into a geographic information system (GIS) to portray habitat suitability values spatially and temporally across systems of the study area. The values vary spatially according to stressor levels throughout the estuary and temporally as a result of cycling of important stressor inputs, such as water temperature and salinity. Areas predicted to be suitable and those predicted to be less suitable or disturbed should be targeted for additional sampling as part of the model validation and adaptive management process.

Species selected for modeling (focal species) are ecologically, recreationally or economically important and have a well-established linkage to stressors of management interest. They may also make good focal species because they engage the public in caring about the outcome of restoration projects. The HSI models were developed by choosing specific life stages of each species with the most limited or restricted range of suitable conditions, to capture the highest sensitivities of the organisms to the environmental changes associated with planned restoration activities. Environmental parameters used in the model, and their sources, are listed in Table 1.

\section{Ecology of Vallisneria americana}

One of the factors contributing to high productivity in estuaries has been the historic abundance of submerged aquatic vegetation (SAV). SAV provides food for waterfowl and a critical habitat for shellfish and finfish. In addition, submerged plants affect nutrient cycling, sediment stability, and water clarity (Batiuk et al. 1992). Because SAV beds provide habitat for benthic and pelagic organisms, many of their water chemistry requirements overlap, including preferred salinity and temperature ranges. However, SAV also serves well as an indicator of water clarity and nutrient levels. Habitat requirements developed for fish and birds do not normally incorporate these conditions. In addition, "many of the restoration goals for fish and birds involve changes in both environmental quality and management of human harvesting activities" (Dennison et al. 1993). In contrast, SAV goals can more directly be linked to environmental and water quality, thus providing for more direct establishment of targets and protection goals in areas of the estuary where SAV is located (Batiuk et al. 1992, Dennison et al. 1993, Doering et al. 2002).

Tape grass, Vallisneria americana, is a salt-tolerant freshwater SAV species that is located in the fresh, oligohaline, and mesohaline portion of estuaries in the eastern United States. Beds of tape grass can occur in the Caloosahatchee estuary up to $30 \mathrm{~km}$ downstream of S-79 (Figure 1: near Area 4), but grow most luxuriantly upstream of Area 3 , especially where their greatest coverage occurs around Area 2 and Beautiful Island (Chamberlain and Doering 1998a,b). Like other populations in Florida (Dawes and Lawrence 1989), tape grass in the Caloosahatchee does not completely die back in the winter as it does in more temperate northern climes. Field observations indicate that mature plants can be found year round that probably are of a sufficient height and density to provide habitat for other organisms. Field observations also indicate that canopy height and shoot density (Figure 2; SFWMD 2003) begin to decline as salinity rises above 10\%o 
(Chamberlain and Doering 1998a, Bortone and Turpin 2000). When conditions are favorable, tape grass exhibits a seasonal pattern of growth, with highest biomass achieved in the late summer (Figure 3; SFWMD 2006), flowering in the late summer to early fall, and a winter decline in biomass (Bortone and Turpin 2000). Laboratory experiments using Caloosahatchee plants also determined that tape grass can grow throughout the year (Figure 4; SFWMD 2003) provided that conducive salinity and sufficient light are available (Barko et al. 1984, Bortone and Turpin 2000). Therefore, freshwater discharge commensurate with a suitable salinity and clarity need not separately account for different seasonal or spatial tolerances (Doering et al. 1999).

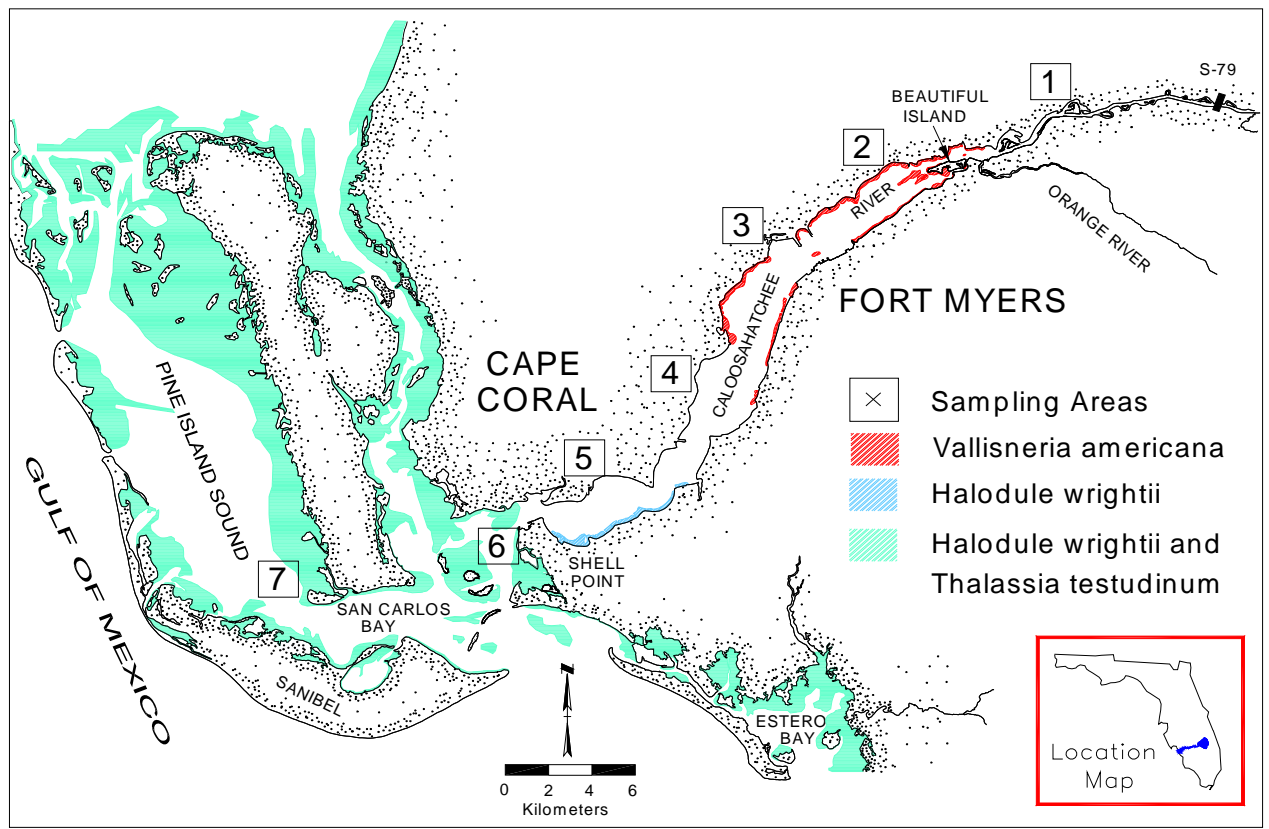

Figure 1. Caloosahatchee estuary sampling areas and distribution of three SAV species: tape grass (Vallisneria americana), shoal grass (Halodule wrightii) and turtle grass (Thalassia testudinum).

CREDIT: Kevin Chartier, University of Florida/IFAS, 2006 


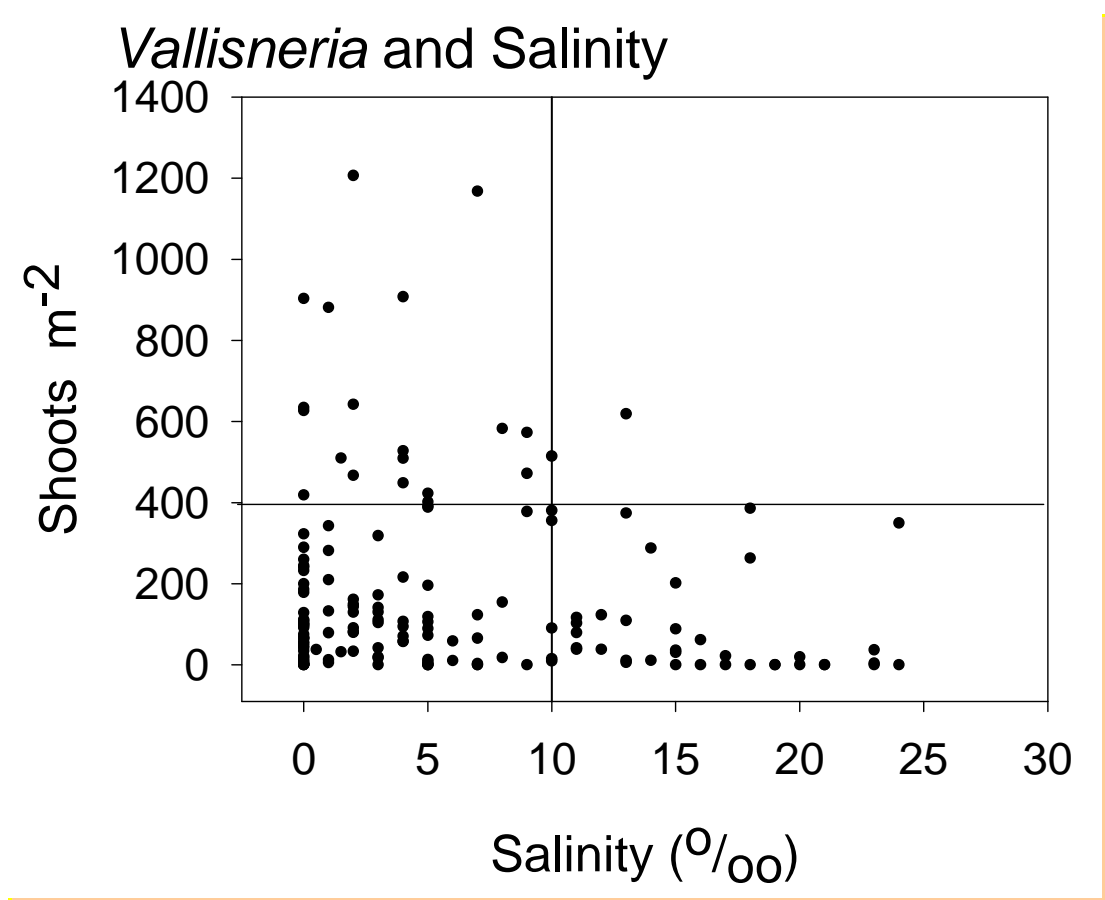

Figure 2. Field survey results of Vallisneria americana shoot counts vs. salinity (SFWMD 2003).

CREDIT: Kevin Chartier, University of Florida/IFAS, 2006

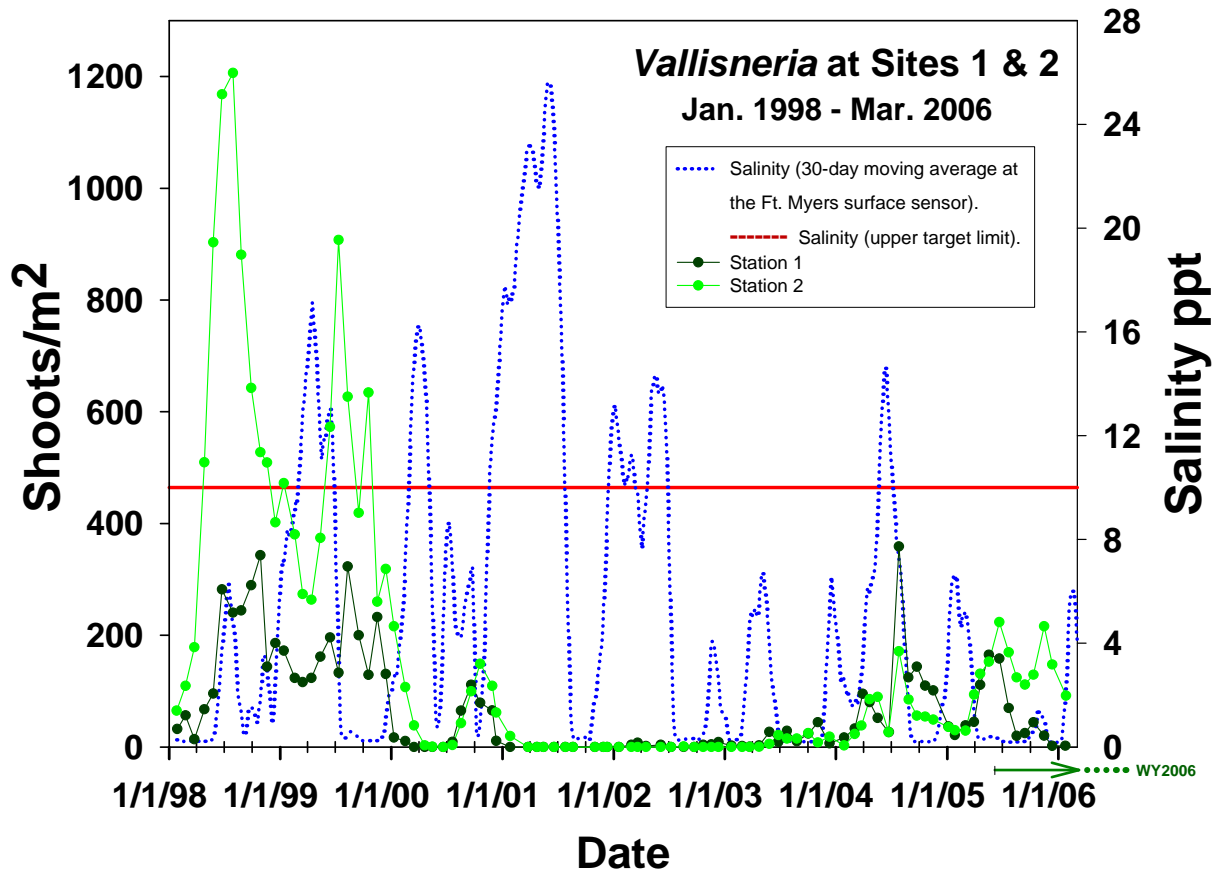

Figure 3. Vallisneria americana shoot density in the upper Caloosahatchee estuary (Sites 1 and 2 in Area 2, Figure 1). Recent data are from stations monitored by the SanibelCaptiva Conservation Foundation and Mote Marine Laboratory (SFWMD 2006).

CREDIT: Kevin Chartier, University of Florida/IFAS, 2006 


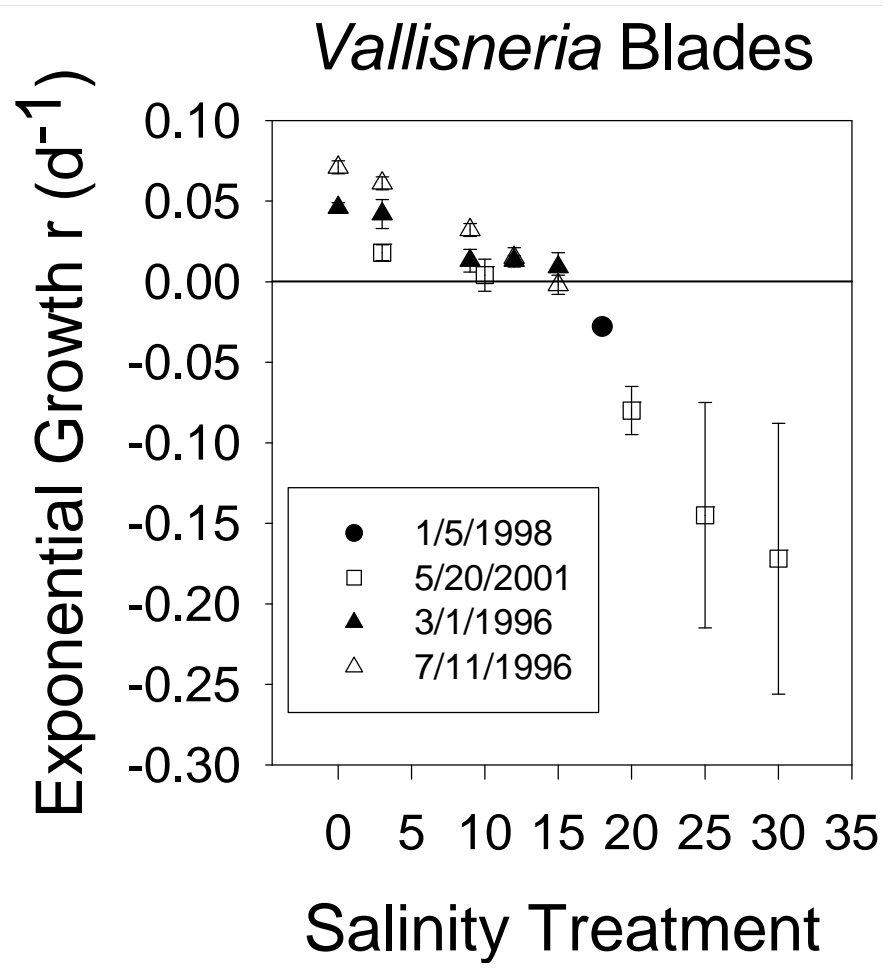

Figure 4. Laboratory experimental results of Vallisneria americana growth rate vs. salinity (SFWMD 2003).

CREDIT: Kevin Chartier, University of Florida/IFAS, 2006

General non-quantitative observations of tape grass during 1956-1989 found that relative abundance greatly varied annually throughout its range (Chamberlain et al. 1995) and indicated that the existence of healthy plants during the winter dry season leads to good coverage, taller plants, and reproduction during the peak summer growing months. Quantitative sampling since 1998 confirms this observation (Bortone and Turpin 2000).

In the upper estuary, temporal and spatial fluctuation in salinity and other important water quality parameters are largely driven by freshwater discharge at S-79. During periods of high discharge, usually during the summer wet season, the system turns fresh. During periods of low discharge during the winter and spring, salt water intrudes up the estuary.

A review of the literature, field studies, and laboratory investigations of tape grass salinity tolerance (SFWMD 2003) were used to establish hydrologic targets for developing the Minimum Flow and Level Rule (as per Florida Administrative Code, Section 40E-8.021(24)). After analysis of historical salinity records from the estuary along with an initial salinity model, a flow of 300 cfs from S-79 (Figure 5) was identified as the average minimum flow needed (SFWMD 2003) to support tape grass growth in the critical region of the estuary where it has historically been most abundant (Figure 1: Area 2). This designated flow volume, along with about $200 \mathrm{cfs}$ input from the tidal tributaries and ground water, should maintain salinity at $\leq 10 \%$ onder average conditions and support tape grass growth. The MFL rule includes two salinity criteria measured near the Ft. Myers Yacht Basin (Figure 1: near Area 3). An MFL exceedence occurs if: (1) the 30- 
day moving average salinity rises above $10 \%$; or (2) a single daily average salinity rises above 20\%. The first criterion recognizes that tape grass in the critical region (Figure 1: Area 2) grows well at salinity below $10 \%$. The second accounts for the effect of exposure to high salinity for short time periods. Upon additional consideration and analysis (Chamberlain 2005, Chamberlain and Doering 2004), a minimum flow of 450 cfs is now promoted to better insure tape grass protection during very dry conditions when the tidal tributary flow contribution is diminished well below the required $200 \mathrm{cfs}$.

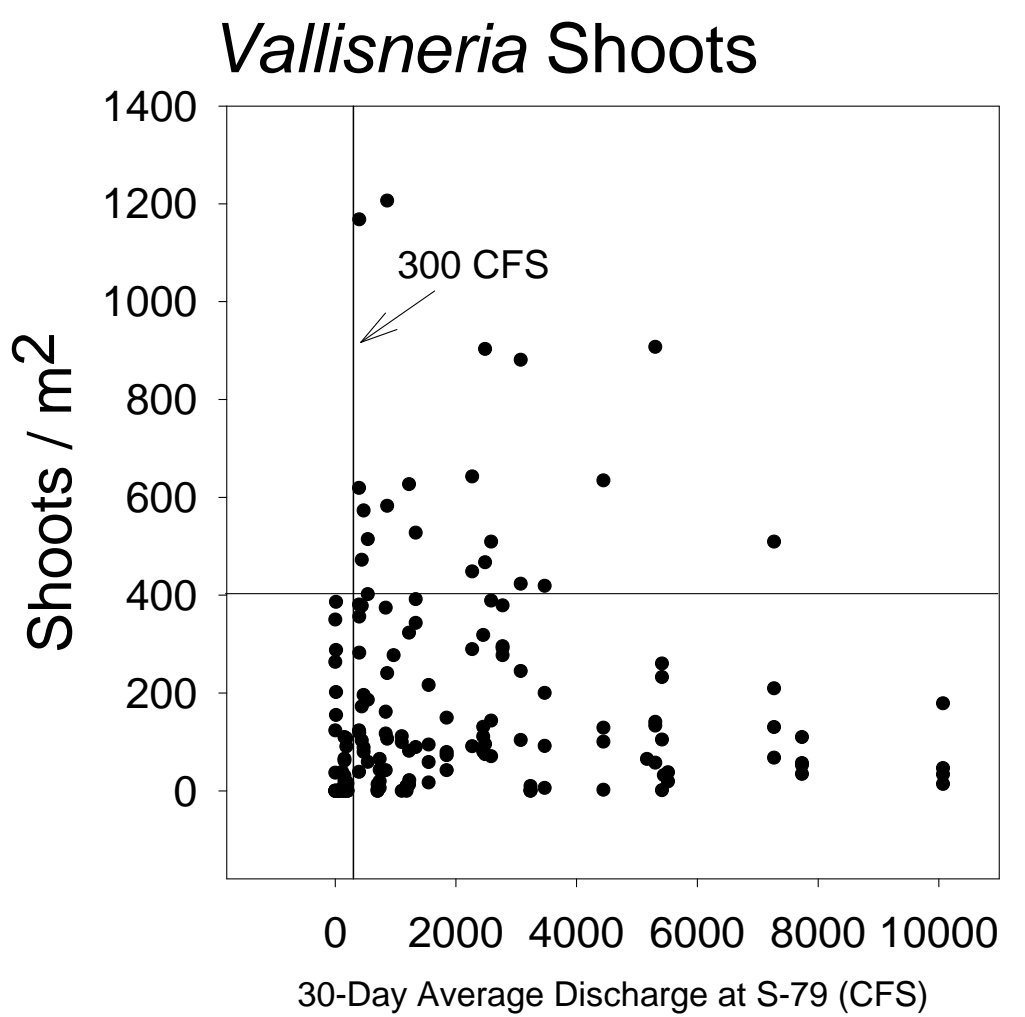

Figure 5. Field survey results of Vallisneria americana shoot counts vs. inflow from S-79 (Doering et al. 2002, SFWMD 2003).

CREDIT: Kevin Chartier, University of Florida/IFAS, 2006

Although viable rosettes (short immature plants) are almost always present, total denuding of the bottom and loss of all plants can occur. This situation became evident after the year 2000 drought (Figure 3). Plants did not return in appreciable numbers after two years, thus confirming significant harm to this portion of the estuary as defined by the MFL Rule (SFWMD 2003).

Doering et al. (1999) reported decreasing growth of tape grass as salinity increased (Figure 3) whereby positive growth became zero when salinity exceeded 10\%. Doering et al. (1999) also found that tape grass survived at $15 \%$ for over 40 days under ample light conditions and mortality was observed at $18 \%$, with a few viable plants persisting after 70 days (Doering et al., 2001). Analysis of long-term records reveals saltwater intrusion into the upper estuary that results in salinity of $\geq 10 \%$ o may last for 
over 100 days, but almost always is less than 70 days. Median durations are five to 12 days. Therefore, approximately $50 \%$ of the intrusion events that occur may last long enough to impact tape grass growth. Peak salinities during these intrusions average 13$14 \%$, which is near the tape grass limit for growth, but approximately $25 \%$ of the peak salinities are $\geq 18 \%$, which can severely reduce coverage and bed morphometrics (Kraemer et al. 1999, Doering et al. 2001). During a field experiment in the Caloosahatchee estuary, Kraemer et al. (1999) found that exposure to salinities approaching $18 \%$ for longer than two weeks to a month resulted in tape grass mortality from which plants did not recover. Based on the results of studies and information discussed above, the HSI curve in Figure 6 was formulated for a model described in Hunt and Doering (2005).

Both long-term and short-term exposures (if repeated) during the late winter may result in tape grass not fulfilling its growth potential needed to provide habitat during the spring and summer season. In addition, other growth parameters, such as water clarity and temperature, can also influence contiguous plant coverage and recovery after population declines. Therefore, rules were developed (Table 2) for applying to the HSI model, in order to insure previous conditions are considered when determining the new HSI value each month.

Research to date indicates that the flow distributions specified by Chamberlain and Doering (2004) should promote good water quality (Doering and Chamberlain 1998, Chamberlain et al. 2003) in the ranges suggested by Dennison et al. (1993). The numeric tape grass model developed by Hunt and Doering (2005) uses salinity, light attenuation, and temperature as independent variables to predict tape grass density. The model confirms that light is an important variable for tape grass growth in the Caloosahatchee. Even though high flows are not a concern for tape grass regarding salinity, they are associated with reduced plant density (Figure 5). Water clarity decreases during increased flows due to suspended solids, color and in some cases increased incident of algal blooms. These factors may contribute to a decrease in tape grass growth, recovery, and distribution throughout the estuary, and the depth at which it can survive.

Batiuk et al. (1992) and Dennison et al. (1993) reviewed water quality requirements for SAV in estuaries and suggested guideline values for water clarity, suspended solids, nutrients, and chlorophyll-a for tape grass (Table 1). In the field transplant studies by Kraemer et al. (1999), salinity tolerances appeared lower than in laboratory experiments, and it was suggested that other factors, particularly light covarying with salinity can influence the distributional limits. Further evidence of the importance of light in this ecosystem was reported by Bortone and Turpin (2000). In a field study, they found $V$. americana biomass to be significantly associated with six factors: location, temperature, depth, secchi depth, TSS and color - making four of the six factors associated with light conditions. Additional laboratory mesocosm experiments were conducted to quantify the effects of light stress at different salinities (Hunt et al., 2003, 2004). Photosynthesis/ Irradiance (P/I) curves were developed and showed that light utilization varies with salinity. Based on this work by Hunt et al. (2003, 2004), two HSI curves were developed for different ranges of salinity. Figures 7 and 8 depict the index values for tape grass response to average daily bottom light (ADBL) when salinity is $<9.5 \%$ and $>9.5 \%$, respectively. Figure 9 provides the formula for calculating ADBL, 
which requires knowing (1) incident light in the PAR (Photosynthetic Active Radiation) spectral range; (2) water column light attenuation (K); and (3) depth. Average monthly incident PAR for the Caloosahatchee is depicted in Figure 10 and was calculated from a daily average PAR dataset, recorded by a continuous sensor during 1998-2004, located in the nearby Estero Bay Watershed. Light attenuation was calculated based on freshwater inflow from S-79 (resulting regression line-Figure 11). This relationship was determined from analysis that predicted secchi disk readings (dependent variable) from the 30-day average S-79 flow volume (cfs). Average daily flow has been recorded by the USGS since 1965; the secchi disk data to support the regression analysis came from field measurements collected intermittently since 1986. Light attenuation (K) is calculated from the predicted secchi value by the formula: -1.65/secchi (Batiuk et al. 1992). Depth was determined from bathymetry surveys of the Caloosahatchee estuary and the resulting information supplied in a GIS data file that matched the grid cell points of the model.

Table 1. Summary of freshwater inflow and water quality requirements for Vallisneria americana in the Caloosahatchee estuary

\begin{tabular}{|c|c|c|}
\hline Estuary Area & Value & Source \\
\hline $\begin{array}{l}\text { Throughout its } \\
\text { range }\end{array}$ & $\begin{array}{l}\text { Water Quality: } \\
\text { (1) Light for Val to } 1 \mathrm{~m} \text { : } \\
\text { (a) atten }\left(\mathrm{K}_{\mathrm{d}}\right)=1.5-2.0 \mathrm{~m}^{-1} \\
\text { (b) Secchi Disk depth }= \\
0.85 \text { to } 1.1 \mathrm{~m} \\
\text { (c) Light saturatn } \sim 150-200 \mu \mathrm{E} / \mathrm{m}^{2} \mathrm{~s} \\
\text { (d) Minimum }\left(\text { model) } \sim 17 \mu \mathrm{E} / \mathrm{m}^{2} \mathrm{~s}\right. \\
\text { (2) Chlorophyll }-\mathrm{a}=15 \mu \mathrm{g} / \mathrm{l} \\
\text { (3) Tot.Susp.Solids }=15 \mathrm{mg} / \mathrm{l} \\
\text { (4) Dissolved Inorg. } \mathrm{N}=0.15 \mathrm{mg} / \mathrm{l} \\
\text { (5) Dissolved Inorg. } \mathrm{P}=0.07 \mathrm{mg} / \mathrm{l} \\
\text { (6) Temperature: } \\
\text { (a) Estimated Min.(model) } \sim 14-16^{\circ} \mathrm{C} \\
\text { (b) Optimum }(\text { model }) \sim 34^{\circ} \mathrm{C} \\
\text { (b) Est'd Max.(model) }>34^{\circ} \mathrm{C},<50^{\circ} \mathrm{C}\end{array}$ & $\begin{array}{l}(1,2,3,4,5) \text { - Batiuk et al. } 1992, \\
\text { Dennison et al. 1993, Chamberlain et al. } \\
2003 \\
(1,6) \text { - Hunt and Doering 2005, } \\
\text { Hunt et al. 2003, } 2004\end{array}$ \\
\hline $\begin{array}{l}\text { Throughout its } \\
\text { range }\end{array}$ & $\begin{array}{l}\text { Salinity: } \\
\text { (1) Optimum growth @ } 0-3 \% \\
\text { (2) Net month growth if: } \\
\text { (a) }<10 \% \\
\text { (b) Exposure @ } 18 \% \leq 5 \text { days } \\
\text { (3) Growth/day cessation } \sim 10-15 \% \\
\text { (4) No net growth in month following } \\
18 \% \text { for } 11-20 \text { days. } \\
\text { (5) Plant growth/day decline as approach } \\
\geq 15 \% \text {. } \\
\text { (6) Month growth potential decreased } \\
\text { after } 1 \text { day @ 18\%o } \\
\text { (7) } 40 \% \text { mortality after } 20 \text { days @ } 18 \% \text { o } \\
\text { (8) Lethal limit @ } \sim 18 \% \sim 2-4 \text { weeks }\end{array}$ & $\begin{array}{l}(1,2,3,5,6,5,7) \text { - Doering et al. 1999, } \\
2001,2002 \\
\text { (2) - Chamberlain and Doering 1998a,b } \\
\text { (8) - Kraemer et al. } 1999\end{array}$ \\
\hline $\begin{array}{l}\text { Target Area2 - } \\
\text { Beautiful Isl. }\end{array}$ & $\begin{array}{l}\text { Salinity targets: } \\
\text { (1) Monthly average }<10 \% \\
\text { (2) } 1 \text { day peak } \leq 18 \% \text { o }\end{array}$ & SFWMD 2003 \\
\hline
\end{tabular}


Ft.MyersBridge Salinity Probe

Salinity targets (MFL):

(1) Monthly average $\leq 10 \%$

(2) 1 day peak $\leq 20 \%$

Target Area2 Beautiful Isl.

Target Area2 Beautiful Isl.
Hydrologic (flow) Targets:

(1) Minimum flow

(a) 450 cfs avg monthly flow @ S-79

(b) combined 500 efs avg monthly flow S-79 \& tidal basin (near \& upstrm Ft.Myers Bridges).

(2) Max flows consistent to protect downstrm SAV (2800-4500 cfs) will prevent exceedence of WQ guidelines.

(3) Defined preferred flow distribution (EST05) that maximizes flows (75\%) in 450-800 cfs range will maximize WQ for growth

Target Plant Morphometricts (June-Sept growing season):

(1) Minimum 20\% of average potential shoot density $\left(\sim 200-300\right.$ shoots $/ \mathrm{m}^{2}$ of potential $\left.>1,000 \mathrm{shts} / \mathrm{m}^{2}\right)$.

(2) Minimum avg. blade length $15 \mathrm{~cm}$

(3) Most years $\geq 500-600 \mathrm{shts} / \mathrm{m}^{2}$

(4) Most years-plant reproduction (sexual)

(5) Run tape grass model to evaluate/select preferred flows
SFWMD 2003

(1) - Chamberlain 2005, Chamberlain et al. 1995, Chamberlain and Doering 2004

(2) - Doering and Chamberlain 1998

(3) - Chamberlain et al. 2003
$(1,2)$ Chamberlain 2005, Chamberlain et al. 2003

(3) - SFWMD 2006

(4) - Doering et al. 1999, 2002

(5) - Hunt et al. 2003, 2004; Hunt and Doering 2005

Temperature is an additional factor that may influence tape grass growth. In general, temperature changes primarily influence growth of SAV over predictable seasonal cycles. In northern environments there is a distinct seasonal growth pattern involving the production of vegetative tubers and winter dormancy period during the cold winter months. Different temperature growth ranges have been reported for $V$. americana in populations growing in different climates and under different environmental conditions. Titus and Adams (1979) report a temperature optimum for $V$. americana of $32.6^{\circ} \mathrm{C}$, obtained from University Bay, Madison, WI. In the Detroit River, $V$. americana grew at water temperatures ranging from 19 to $31.5^{\circ} \mathrm{C}$ (Hunt 1963). Barko et al. (1982, 1984) reported growth of commercially obtained juvenile plants was severely restricted below $20^{\circ} \mathrm{C}$.

Consistent with the southern ecotype of $V$. americana reported by Smart and Dorman (1993), no over-wintering buds or tubers have been reported in the Caloosahatchee estuary. The acute limits or effects of the colder winter water temperatures on the growth and survival in Florida are not known. Water temperatures in the upper Caloosahatchee estuary over the period $1998-2005$ have varied from $14^{\circ} \mathrm{C}$ in the winter to $34^{\circ} \mathrm{C}$ in the summer. Inter-annual variation in seasonal high and low water temperatures are also apparent over this time period. Lower water temperature during some years may adversely impact tape grass. High freshwater inflow that increases water 
color may result in dark water that absorbs solar energy and raises water temperature near tape grass tolerance limits. Given the span in water temperatures in the Caloosahatchee estuary - ranging from potentially above-optimal conditions to below tolerance levels in any given year - and the importance of over-wintering survival, water temperature may be an important variable that influences $V$. americana survival.

A habitat suitability temperature curve (Figure 12) was developed for tape grass in the Caloosahatchee based on an equation of O'Neill et al. (1972). Input values for the lower lethal, optimum, and upper lethal limits came from general literature values (not specific to Florida) and calibrated based on a growth model described by Hunt and Doering (2005). Non-linear regression was employed to predict daily average temperature in the Caloosahatchee estuary using historical data collected by continuous sensors since 1992 (Figure 13). As a daily average data set predicted from historical records, it does not reflect the high or low conditions that might be expected in any given year.

\section{Habitat Suitability Index for Vallisneria americana}

The HSI for tape grass includes four components: the previous month's HSI score, salinity, light availability, and temperature. Parameters for each variable are described and presented in graphs below. The habitat suitability index is calculated monthly as the weighted geometric mean of the four specific environmental variables.

\section{HSI Formula}

Calculated monthly:

HSI $=$ Previous $^{\mathrm{w}} *$ Salinity $^{\mathrm{w}} *$ Light $^{\mathrm{w}} *$ Temperature $\left.^{\mathrm{w}}\right)$

\section{Previous}

"Previous" variable included because current month’s HSI score should depend on the how well the grass was doing last month (previous score).

Previous = previous_month_HSI score + 0.05 (not to exceed 1.0), in order to allow for growth from month to month if other conditions are suitable.

Table 2. Changes to HSI model's spatial boundaries (A) and post-processing routines (B and $\mathrm{C}$ ) for adjusting the final HSI ecological model scores to better reflect long-term impacts of severe reduction in Vallisneria americana density due to low HSI scores of environmental variables (salinity, light and temperature in above model formula).

\begin{tabular}{|l|l|l|}
\hline Routine & Model output criteria & Model score adjustment \\
\hline A. & Establish a lower depth threshold of $5 \mathrm{ft}$ & Model areas $>5$ feet are not scored \\
\hline B. & If HSI score $\leq 0.2$ for one month, & Then HSI remains $\leq 0.2$ for remainder of the season \\
\hline C. & If HSI score $\leq 0.1$ for one month, & Then HSI $=0$ for 12 subsequent months \\
\hline
\end{tabular}


Adjustments were agreed to by ecological benefits sub-team (6/14/06)

HSI Curves and Application (for determining input values to HSI model formula)

\section{Salinity}

The freshwater inflow associated with base conditions and management alternatives serves as input for the hydrodynamic model (CH3D with regression routine) that estimates salinity concentration at key locations in the estuary. An immolator program used the salinity output to further estimate salinity at the remaining model grid cells. This salinity was compared to the curve in Figure 6 to determine the HSI score for that grid cell and input to the model formula.

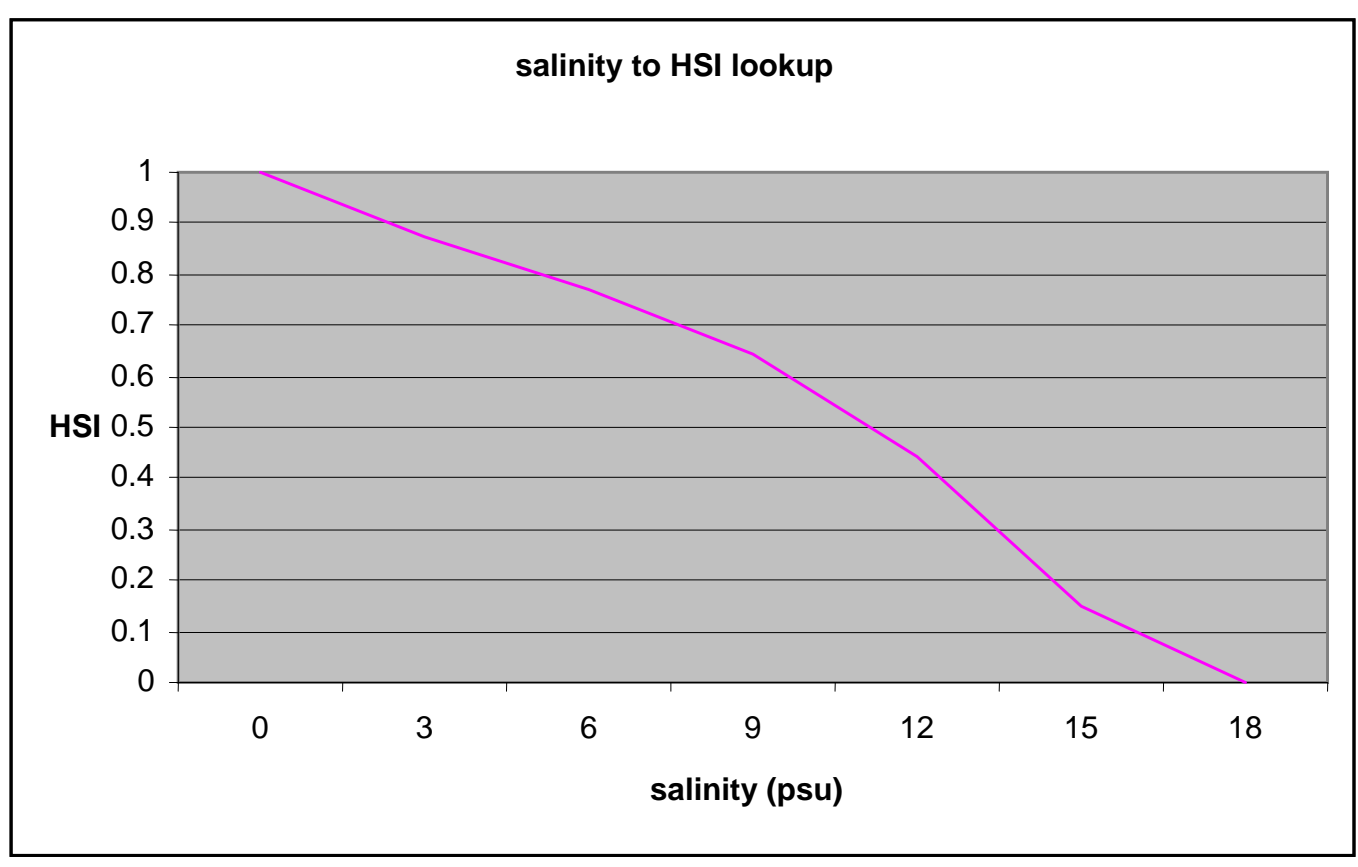

Figure 6. HSI value for Vallisneria americana response to salinity (formulated from Doering et al. 1999; Hunt and Doering 2005).

CREDIT: Leonard Pearlstine, University of Florida/IFAS, 2006 


\section{Light Availability}

The formula in Figure 9 was employed to calculate the average daily bottom light (ABDL) during the month. The average incident PAR component of this formula, for the month of interest, is supplied by the data values associated with Figure 10. The light attenuation (K) component was supplied by the data values associated with Figure 11, which depend on the average flow for the month. Depth data were supplied from a GIS file with survey data that matched the model grid cell points. Once the ADBL value is determined for the month, it is used to estimate the index score as depicted in Figures 7 or 8 , depending on the salinity value for the model cell during the month.

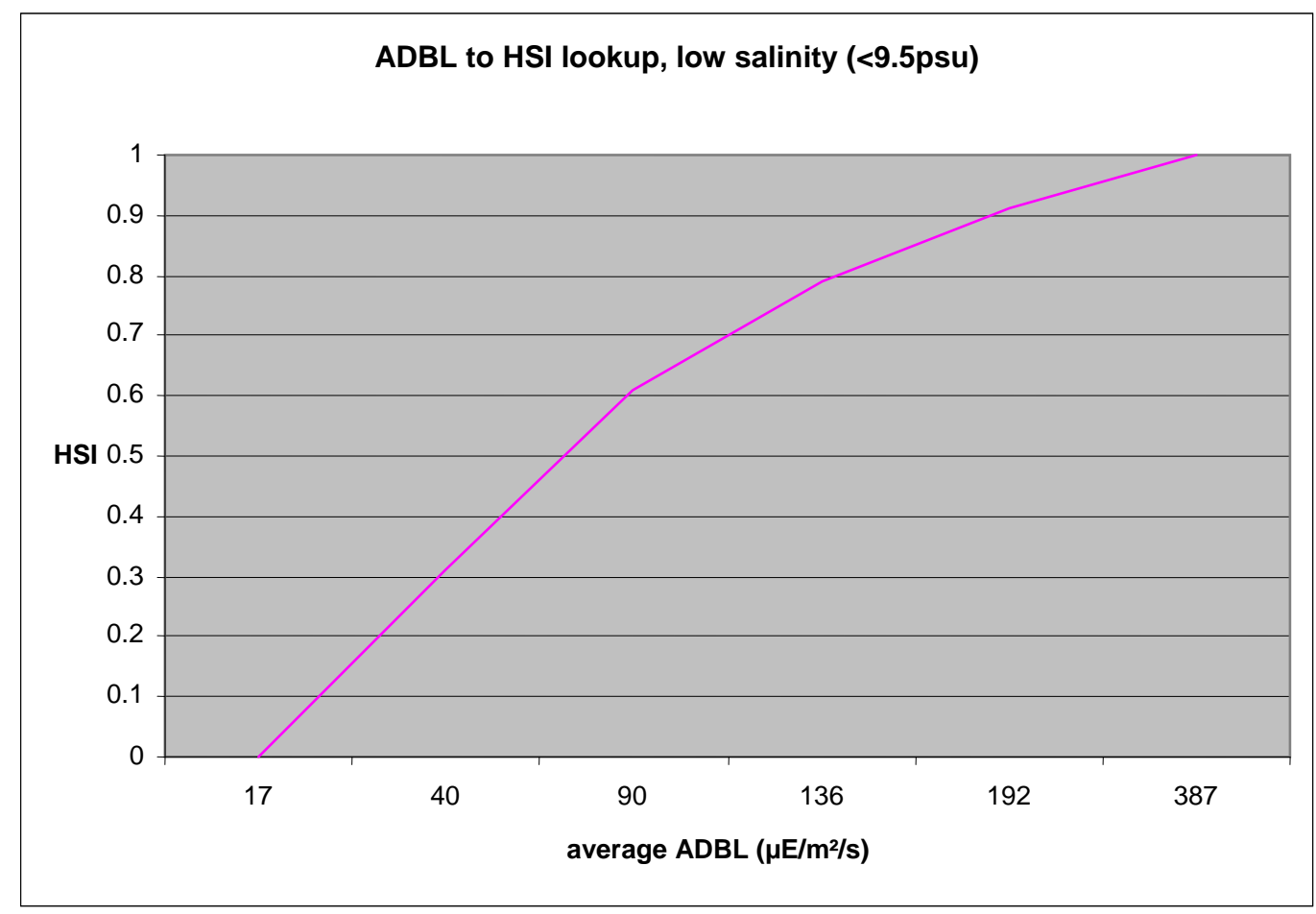

Figure 7. HSI value for Vallisneria americana response to average daily bottom light in low salinity ( $<9.5 p s u$ ) conditions (Hunt et al. 2004, 2003; Hunt and Doering 2005). CREDIT: Leonard Pearlstine, University of Florida/IFAS, 2006 


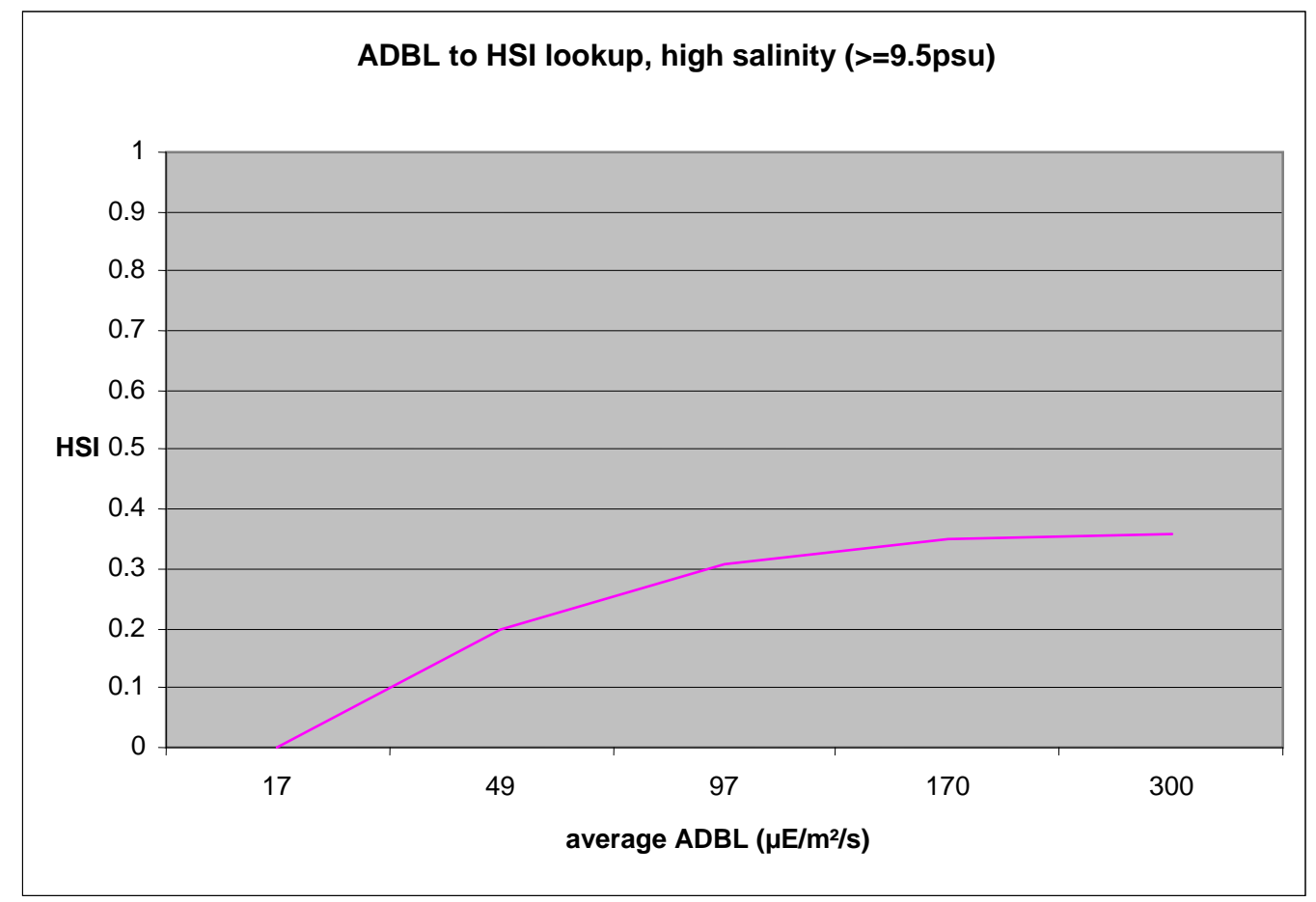

Figure 8. HSI value for Vallisneria americana response to average daily bottom light in high salinity ( $\geq 9.5 p s u$ ) conditions (Hunt et al. 2004, 2003; Hunt and Doering 2005). CREDIT: Leonard Pearlstine, University of Florida/IFAS, 2006

$\mathrm{ADBL}=(\text { average monthly incident PAR })^{*}(1$-surface reflectance $) * \mathrm{e}^{-\mathrm{K} * \mathrm{depth}}$; surface reflectance $=0.9 *$ incident $P A R$

Figure 9. Equation to determine ADBL.

CREDIT: Leonard Pearlstine, University of Florida/IFAS, 2006 


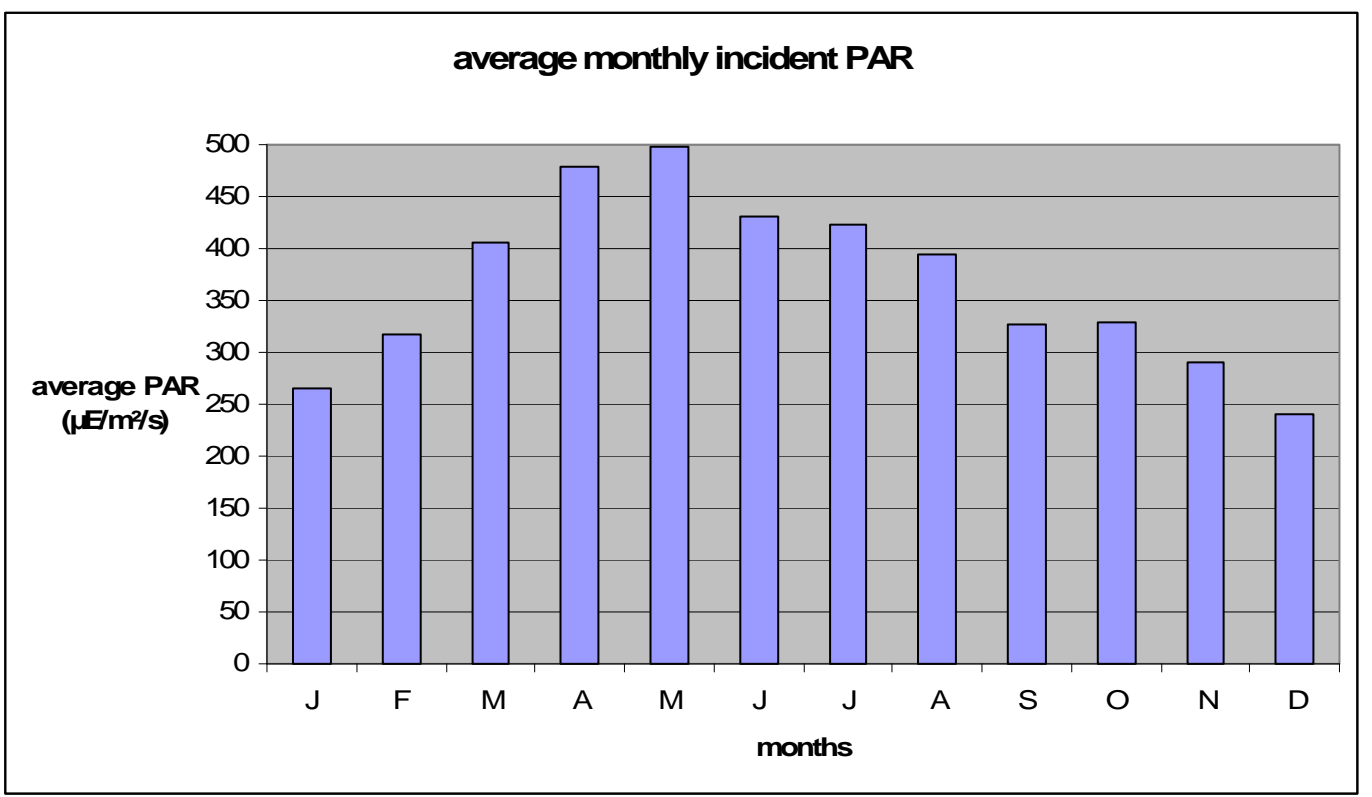

Figure 10. Average monthly incident PAR (calculated from daily average PAR measurements collected during 1998-2004 at a continuous recording station in the Estero Bay watershed).

CREDIT: Leonard Pearlstine, University of Florida/IFAS, 2006

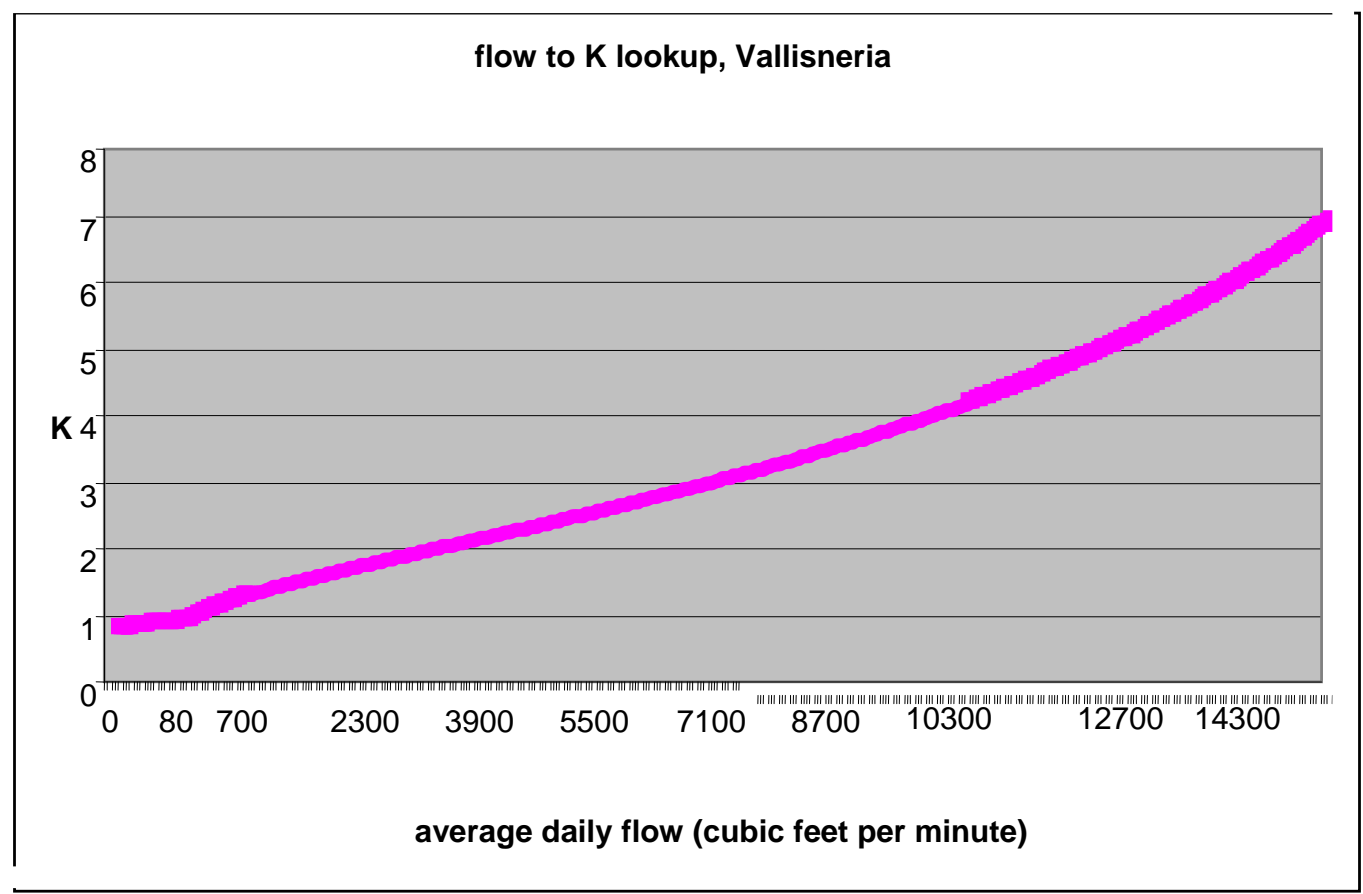

Figure 11. HSI relationship between average daily flow and light attenuation (K values). CREDIT: Leonard Pearlstine, University of Florida/IFAS, 2006 


\section{Temperature}

Daily average temperature was estimated from continuous in-water recorders that have been measuring near surface temperature since 1992. Depending on the HSI model requirements, these daily values (Figure 13) can be averaged over the time period of interest (e.g., monthly average). The resulting temperature is then used to determine the index value in Figure 12 for input to the HSI model formula.

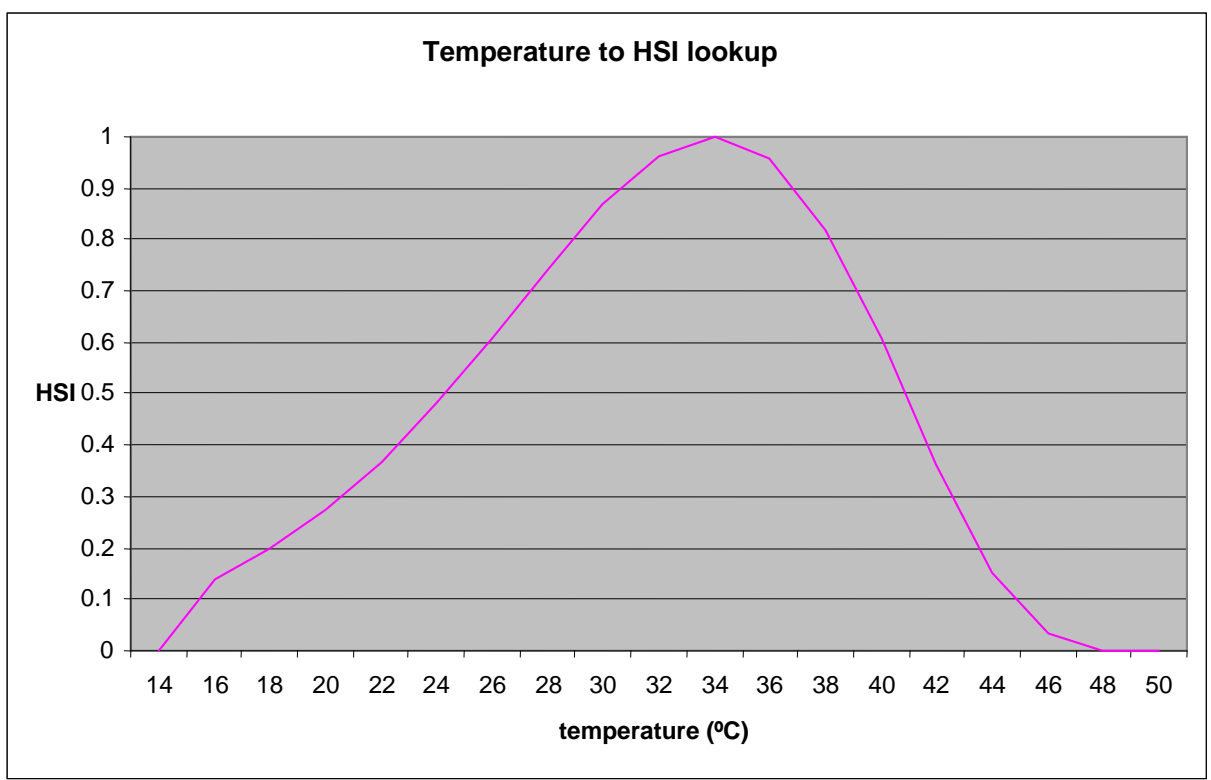

Figure 12. HSI value for Vallisneria americana response to temperature (O'Neill et al. 1972, Hunt and Doering 2005).

CREDIT: Leonard Pearlstine, University of Florida/IFAS, 2006 


\section{Predicted Daily Temperature}

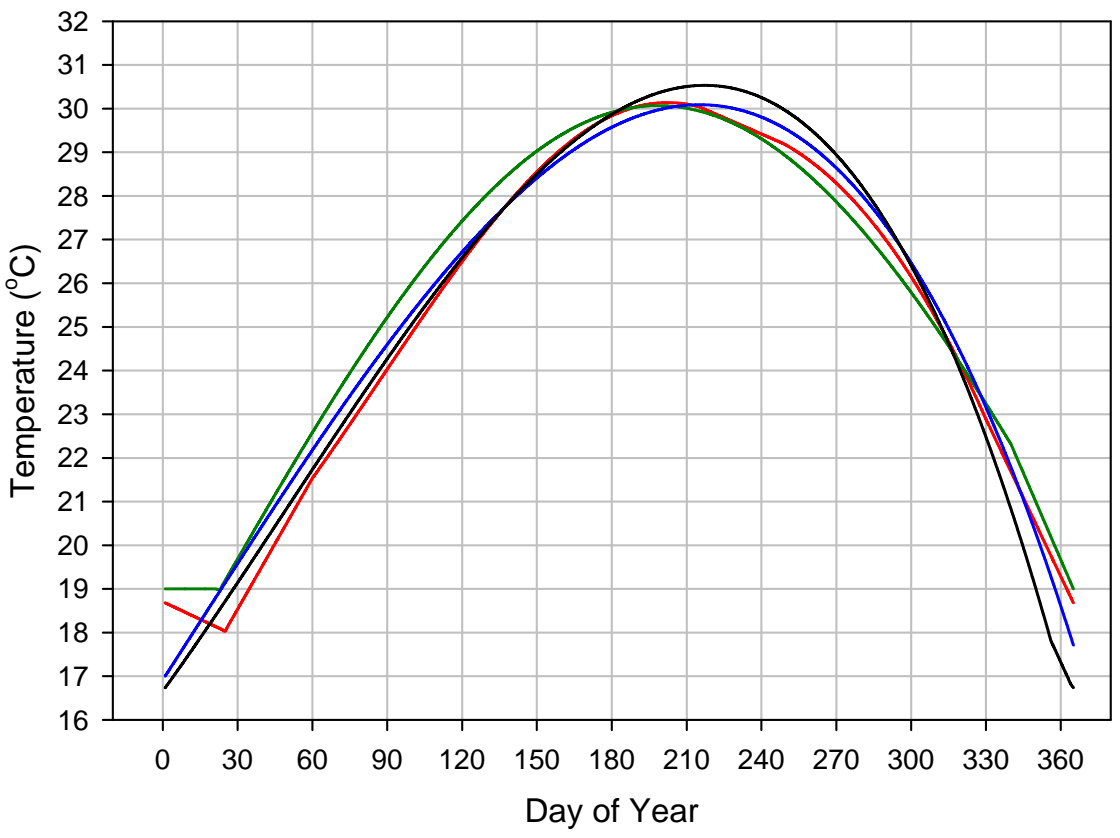

$$
\begin{aligned}
& \text { Day of Year vs Predicted Shallow Temp @ S-79 } \\
& \text { - Day of Year vs Predicted Shallow Temp @ Br-31 } \\
& \text { Day of Year vs Predicted Shallow Temp @ FtM } \\
& \text { Day of Year vs Predicted Shallow Temp @ Shell Pt. and Sanibel Causeway }
\end{aligned}
$$

Figure 13. Daily average temperature estimated from historical records in the Caloosahatchee.

CREDIT: Kevin Chartier, University of Florida/IFAS, 2006 


\section{References Cited}

Barko, J. W., D. G. Hardin and M. S. Matthews. 1982. Growth and morphology of submerged freshwater macrophytes in relation to light and temperature. Canadian J. Bot. 60:877-887.

Barko, J. W., D. G. Hardin, and M. S. Matthews. 1984. Interactive Influences of Light and Temperature on the Growth and Morphology of Submerged Freshwater Macrophytes. Technical Report A-84-3, U. S. Army Corps of Engineers, Waterways Experimental Station, Vicksburg, Miss. 24 pp.

Barnes, T. K. and F. J. Mazzotti. 2005. Using Conceptual Models to Select Ecological Indicators for Monitoring Restoration and Management of Estuarine Ecosystems. In Estuarine Indicators, ed. S.A. Bortone, 493-450. Boca Raton, FL: CRC Press.

Batiuk, R. A., R. J. Orth, K. A. Moore, W. C. Dennison, J. C. Stevenson, L. W. Staver, V. Carter, N. B. Rybicki, R. E. Hickman, S. Kollar, S. Bieber, and P. Heasly 1992.

Chesapeake Bay submerged aquatic vegetation habitat requirements and restoration targets: A technical synthesis. Chesapeake Bay Program CBP/TRS 83/92 186 pp.

Bortone, S. A., and R. K. Turpin. 2000. Tape grass life history metrics associated with environmental variables in a controlled estuary. In: Bortone, S.A. (ed.), Seagrasses: Monitoring, Ecology, Physiology, and Management. CRC Press, Boca Raton, Florida, pp. 65-79.

Chamberlain, R. H. 2005. C-43 Basin Storage Reservoir Project - Caloosahatchee Estuary Hydrologic Evaluation Performance Measures. C-43 BSR Study Team Adopted Draft, June 28, 2005.

Chamberlain, R. H. and P. H. Doering. 1998a. Freshwater inflow to the Caloosahatchee Estuary and the resource-based method for evaluation, p. 81-90. In S.F. Treat (ed.), Proceedings of the 1997 Charlotte Harbor Public Conference and Technical Symposium. South Florida Water Management District and Charlotte Harbor National Estuary Program, Technical Report No. 98-02. Washington, D.C.

Chamberlain, R. H. and P. H. Doering. 1998b. Preliminary estimate of optimum freshwater inflow to the Caloosahatchee Estuary: A resource-based approach, p. 121-130. In S.F. Treat (ed.), Proceedings of the 1997 Charlotte Harbor Public Conference and Technical Symposium. South Florida Water Management District and Charlotte Harbor National Estuary Program, Technical Report No. 98-02. Washington, D.C.

Chamberlain, R. H. and P. H. Doering. 2004. Recommended Flow Distribution (the Caloosahatchee Estuary and the C-43 basin Storage Reservoir Project). Technical Memorandum, South Florida Water Management District. 
Chamberlain, R. H., P. H. Doering, and K. M. Haunert. 2003. Preliminary assessment of water quality and material loading in the Caloosahatchee Estuary, FL. Poster Presentation, $17^{\text {th }}$ Biennial Conference of the Estuarine Research Federation.

Chamberlain, R. H., D. E. Haunert, P. H. Doering, K. M. Haunert, and J. M. Otero. 1995. Preliminary estimate of optimum freshwater inflow to the Caloosahatchee Estuary, Florida. Technical report, South Florida Water Management District, West Palm Beach, Florida.

Dawes, C. J. and J. M. Lawrence. 1989. Allocation of energy resources in the freshwater angiosperms Vallisneria americana Michx. and Potomogeton pectinatus L. in Florida. Florida Scientist. Volume 52: pp 59-63.

Dennison, W. C., R. J. Orth, K. A. Moore, J. C. Stevenson, V. Carter, S. Kollar, P. W. Bergstrom and R. A. Batiuk. 1993. Assessing water quality with submersed aquatic vegetation. Bioscience 43(2):86-94.

Doering, P. H. and R. H. Chamberlain 1998. Water quality in the Caloosahatchee Estuary, San Carlos Bay and Pine Island Sound. Proceedings of the Charlotte Harbor Public Conference and Technical Symposium; 1997 March 15-16; Punta Gorda, FL. Pp 229-240. Charlotte Harbor National Estuary Program Technical Report No. 98-02. 274 pp.

Doering, P. H., R. H. Chamberlain, K. M. Donohue, and A. D. Steinman. 1999. Effect of salinity on the growth of Vallisneria americana Michx. from the Caloosahatchee Estuary, Florida. Florida Scientist. Vol. 62, No.2. pp. 89-105.

Doering, P. H., R. H. Chamberlain, and D. E. Haunert. 2002. Using submerged aquatic vegetation to establish minimum and maximum freshwater inflows to the Caloosahatchee Estuary, Florida. Estuaries 25 (1343-1354).

Doering, P. H., R. H. Chamberlain, and J. M. McMunigal. 2001. Effects of simulated saltwater intrusions on the growth and survival of wild celery, Vallisneria americana, from the Caloosahatchee Estuary (South Florida). Estuaries. Vol. 24. No. 6A, pp. 894903.

Hunt, G. S. 1963. Wild Celery in the lower Detroit River. Ecology 44:360-370.

Hunt, M. J. 2003. An Ecological Model to Predict V. americana Densities in the Upper Caloosahatchee Estuary. In Proceedings of Greater Everglades Restoration Science Conference, Palm Harbor, FL. April 13-18.

Hunt, M. J. and P. H. Doering. 2005. Significance of Considering Multiple Environmental Variables When Using Habitat as an Indicator of Estuarine Condition. In Bortone, S. A. (ed.), Estuarine Indicators, CRC Press, Boca Raton, Fl, pp.221-227. 
Hunt, M. J., P. H. Doering, R. H. Chamberlain, and K. M. Haunert. 2003. Light and Salinity Stress for SAV Determined by Modeling and Experimental Work in the Oligohaline Zone of an Estuary. In Proceedings of Estuarine Research Federation, Seattle, WA. September.

Hunt, M. J., P. H. Doering, R. H. Chamberlain, and K. M. Haunert. 2004. Grass Bed Growth and Estuarine Condition: Is size a Factor worth Considering? In Conference Proceedings of the Southeastern Estuarine research Society, Harbor Branch Oceanographic Institution, Fort Pierce, FL. April 15-17.

Kraemer, G. P., R. H. Chamberlain, P. H. Doering, A. D. Steinman, and M. D. Hanisak. 1999. Physiological responses of transplants of the freshwater angiosperm Vallisneria americana along a salinity gradient in the Caloosahatchee Estuary (Southwestern Florida). Estuaries. Vol. 22, No. 1 pp. 138-148.

Ogden, J. C., S. M. Davis, and L. A. Brandt. 2003. Science Strategy for a Regional Ecosystem Monitoring and Assessment Program. In Monitoring Ecosystems, eds. D.E. Busch and J.C. Trexler, 135-163. Washington, DC: Island Press.

O'Neill, R. V., R. A. Goldstein, H. H. Shugart, and J. B. Manki. 1972. Terrestrial Ecosystem Energy Model. U.S. IBP Eastern Deciduous Forest Biome Memo Report 7219. Oak Ridge National Laboratory, Oak Ridge, TN.

Smart, R. M., and J. D. Dorman. 1993. Latitudinal differences in the growth strategy of a submerged aquatic plant: ecotype differences in Vallisneria americana? Bull.Ecol. Soc. Am. 74 (Suppl.):439.

South Florida Water Management District. 2003. Technical Documentation to Support Development of Minimum Flows and Levels for the Caloosahatchee River and Estuary, Status Update Report. May 2003.

South Florida Water Management District. 2006. South Florida Environmental Report (Draft). Chapter 12 - Caloosahatchee River, Estuary, and Southern Charlotte Harbor.

Titus, J. E. and M. S. Adams. 1979. Coexistence and the comparative light relations of the submerged macrophytes Myriophylulum spicatum L. and Vallisneria americana Michx. Oecologia. 40:273-286.

Wilhere, G. F. 2002. Adaptive management in habitat conservation plans. Conserv. Biol. 16(1): 20-29.

\footnotetext{
${ }^{1}$ This document is CIR 1524, one of a series of the Department of Wildlife Ecology and Conservation, Florida Coopertive Extension Service, Institute of Food and Agricultural Sciences, University of Florida. First published: January 2008. Please visit the EDIS Web site at http://edis.ifas.ufl.edu
} 
${ }^{2}$ Frank J. Mazzotti, Associate Professor, Fort Lauderdale Research and Education Center (FLREC), Institute of Food and Agricultural Sciences (IFAS), University of Florida (UF); Leonard G. Pearlstine, Assistant Scientist, FLREC/IFAS/UF; Robert H. Chamberlain, Lead Environmental Scientist, South Florida Water Management District (SFWMD); Melody J. Hunt, Senior Environmental Scientist, SFWMD; Tomma Barnes, Consultant, Post, Buckley, Schuh \& Jernigan, Inc. (PBS\&J, Inc.); Kevin Chartier, GIS Applications Developer, FLREC/IFAS/UF; and Donald DeAngelis, Landscape Ecologist, U.S. Geological Survey/University of Miami.

The Institute of Food and Agricultural Sciences (IFAS) is an Equal Opportunity Institution authorized to provide research, educational information and other services only to individuals and institutions that function with non-discrimination with respect to race, creed, color, religion, age, disability, sex, sexual orientation, marital status, national origin, political opinions or affiliations. For more information on obtaining other extension publications, contact your county Cooperative Extension service.

U.S. Department of Agriculture, Cooperative Extension Service, University of Florida, IFAS, Florida A. \& M. University Cooperative Extension Program, and Boards of County Commissioners Cooperating. Larry Arrington, Dean.

\section{Copyright Information}

This document is copyrighted by the University of Florida, Institute of Food and Agricultural Sciences (UF/IFAS) for the people of the State of Florida. UF/IFAS retains all rights under all conventions, but permits free reproduction by all agents and offices of the Cooperative Extension Service and the people of the State of Florida. Permission is granted to others to use these materials in part or in full for educational purposes, provided that full credit is given to the UF/IFAS, citing the publication, its source, and date of publication. 